\title{
Pengaruh Bimbingan Imajinasi Terhadap Penurunan Stress Hospitalisasi Pada Anak Usia Sekolah 7-12 Tahun
}

\author{
Niar $^{1}$, Fransiska Firna ${ }^{2}$ \\ 1,2 Program Studi DIII Kebidanan, STIKES Bina Generasi Polewali, Indonesia
}

\begin{tabular}{l} 
Article Info \\
Article history: \\
Received 06-09-2021 \\
Revised 15-11-2021 \\
Accepted 27-11-2021 \\
\\
\hline Keyword: \\
Guidance, imagination, \\
stress, hospitalization
\end{tabular}

Article Info

Article history:

\begin{abstract}
Hospitality stress is an unpleasant experience due to the incompatibility of individual conditions with the environment accompanied by changes in behavior. The purpose of this study was to determine the effect of imagination guidance on reducing stress hospitalization for school children aged 7-12 years in the Asoka Treatment Room in Polewali Mandar Hospital. Imagery guidance is a technique that can be used at home and can help to relax and get rid of the burden of thoughts or stress that is being experienced. This research is an experimental research with research design is a quasy experiment with pre and post test design. The sampling technique used in this study was Accidental Sampling with 22 respondents as the research subjects. In this study data collection using observation sheets. Data analysis used the McNemar test to see the effect on a measurement measurement with a significance level of $\alpha=0.05$. Data processing results were carried out using data analysis with McNemar test which showed that there was an effect of Imagination Guidance on Decreasing Stress Hospitalization with a significant level of $p=0,000$
\end{abstract}

\begin{abstract}
Abstrak
Stres Hospitalisasi adalah pengalaman yang tidak menyenangkan disebabkan ketidaksesuaian kondisi individu dengan lingkungan yang disertai adanya perubahan tingkah laku. Tujuan Penelitian ini adalah untuk mengetahui Pengaruh bimbingan imajinasi terhadap penurunan stress hospitalisasi pada anak usia sekolah 7-12 Tahun di Ruang PerawatanAsoka di RSUD Polewali Mandar. Bimbingan imajinasi adalah teknik yang dapat digunakan dirumah dan dapat membantu untuk bersantai serta menyingkirkan beban pikiran atau stress yang sedang dialami. Penelitian ini merupakan penelitian Eksperimen dengan desain penelitian adalah quasy experiment dengan rancangan pre dan post test. Tekhnik sampling yang digunakan pada penelitian ini adalah Accidental Sampling dengan subjek penelitian sebanyak 22 responden. Dalam penelitian ini pengumpulan data menggunakan lembar observasi. Analisis data menggunakan uji Mc-Nemar untuk melihat pengaruh pada satu varaibel pengukuran dengan tingkat kemaknaan $\alpha=0,05$. Hasil pengolahan data yang dilakukan dengan menggunakan analisa data dengan uji Mc Nemar yang menunjukkan ada Pengaruh Bimbingan Imajinasi terhadap Penurunan Stress Hospitalisasi dengan tingkat signifikan $p=0,000$
\end{abstract}

Corresponding Author:

Niar,

Program Studi DIII Kebidanan,

STIKES Bina Generasi Polewali Mandar,

Mr Muh Yamin No.195, PolewaliMandar Regency, West Sulawesi, Indonesia

Email:niaragus19@gmail.com 
e-ISSN: 2541-4542

\section{PENDAHULUAN}

Stres Hospitalisasiadalah pengalaman yang tidak menyenangkan disebabkan ketidaksesuaian kondisi individu dengan lingkungan yang disertai adanya perubahan tingkah laku [1],Hospitalisasi adalah suatu keadaan yang menunjukkan bahwa anak tersebut berada pada fase krisis atau sakit sehingga dilakukan perawatan di rumah sakit[2]Tujuan Penelitian ini adalah untuk mengetahui Pengaruh bimbingan imajinasi terhadap penurunan stress hospitalisasi pada anak usia sekolah 7-12 Tahun di Ruang Perawatan Asoka di RSUD Polewali Mandar. Bimbingan imajinasi adalah teknik yang dapat digunakan dirumah dan dapat membantu untuk bersantai serta menyingkirkan beban pikiran atau stress yang sedang dialami[3]

Setiap Anak adalah makhluk yang unik yang memiliki kebutuhan sangat berbeda dengan orang dewasa, namun dalam pelayanannya anak bukanlah miniature bagi orang dewasa [4] dimana pada masa anak masih berada pada tahap pertumbuhan dan perkembangan sampai usia remaja. Pertumbuhan anak meliputi perubahan ukuran secara fisik sedangkan perkembangan merupakan suatu proses pematangan dalam kemampuan psikomotorik halus pada anak menjadi lebih matang yang meliputi perubahan sikap, perilaku, kemampuan dalam mengambil keputusan menjadi lebih logis dan terarah [5], perkembangan adalah perubahan kecakapan, kematangan fisik, emosi dan fikiran menuju ke arah dewasa,hal ini yang dapat menyebabkan anak akan mengalami perubahan emosi [6]Berdasarkan survei dari WHO pada tahun 2008, hampir 80\% anak mengalami perawatan di rumah sakit. Sedangkan di Indonesia sendiri berdasarkan survei kesehatan ibu dan anak tahun 2010 didapatkan hasil bahwa dari 1.425 anak mengalami dampak hospitalisasi, dan 33,2\% diantaranya mengalami dampak hospitalisasi berat,41,6\% mengalami dampak hospitalisasi sedang, dan 25,2\% mengalami dampak hospitalisasi ringan Anak usia sekolah yang dirawat inap akan mengalami beberapa masalah seperti mengalami suatu perpisahan, penyesuaian dengan lingkungan yang baru, penyesuaian dengan perawat yang mengurusnya dan bergaul dengan anak yang sakit.

Perpisahan merupakan stress terbesar yang di timbulkan oleh anak yang rawat inap. Salah satu faktor yang mempengaruhi stress akibat rawat inap adalah kehilangan kendali. Banyak situasi rumah sakit yang menurunkan jumlah kendali yang dirasakan oleh anak.Kehilangan kendali pada anak disebabkan oleh perubahan rutinitas,misalnya bermain dan ketergantungan yang harus dipatuhi penelitian ini dilakukan oleh peneliti [7].Salah satu masalah dari anak ini berpusat pada kebosanan [8]Penelitian sebelumnya telah 
dilakukan dengan hasil Skor stress hospitalisasi berada pada rentang 43-37 sebelum dilakukan intervensi hospitalisasi, setelah dilakukan intervensi mengalami perubahan yang signifikan yaitu 38-76. Pada kelompok kontrol sebelum hospitalisasi berada pada angka 41-67, setelah dilakukan hospitalisasi menjadi 47-70, hal ini menunjukkan bahwa ada perubahan yang berarti sebelum dan sesudah dilakukan intervensi dengan metode rekaman audio [9]. Penurunan stress pada anak yang sedang dilakukan perawatan dapat dialkukan melalui bibliografi agar kecemasan dan stress berkurang [10] kecemasan dan stress pada anak juga dapat dilkukan dengan mengajak bermain, salah satu metode yang bisa gunakan dengan member permainan Slime, karena permainan ini memiliki warna cerah dan tekstur yang lembut [11]

Kecemasan merupakan perasaan yang paling umum dialami oleh pasien anak yang mengalami hospitalisasi. Kecemasan yang sering dialami seperti menangis, dan takut pada orang baru. Salah satu metode yang dapat dilakukan mengurangi kecemasan pada anak yaitu terapi distraksi Audiovisual ([12]Banyaknya stressor yang dialami anak ketika menjalani hospitalisasi menimbulkan dampak negative yang mengganggu perkembangan anak. Lingkungan rumah sakit dapat merupakan penyebab stress dan kecemasan pada anak ([13]) Penurunan daya tahan tubuh pada anak dapat disebabkan beberapa faktor seperti asupan nutrisi, cuaca yang berubah-ubah, penyakit, keturunan, dan adanya cedera yang membutuhkan penanganan medis, hal ini merupakan penilaian untuk menentukan anak dalam keadaan sehat atau sakit.

Keperawatan anak merupakan suatu upaya untuk menjaga kesehatan serta mengembalikan fungsi yang optimal dalam Upaya Mempertahankan kesehatan pada anak [14] Anak akan mengalami stres karena lingkungan yang baru bagi anak Sakit dan dirawat di rumah sakit merupakan krisis utama yang tampak pada anak. Jika seorang anak dirawat di rumah sakit, maka anak tersebut akan mudah mengalami krisis karena anak mengalami stress akibat perubahan yang dialaminya. Maka dari itu anak tetap diberi kebebasan dalam bermain saat di rumah sakit [15]. Perubahan tersebut dapat berupa perubahan status kesehatan anak, lingkungan, maupun perubahan kebiasaan sehari-hari [16] untuk melihat apakah pengaruh stress hospitalisasi pada anak usia sekolah 7-12 tahun dengan ini dilakukan studi pendahuluan menggunakan metode bimbingan imajinasi. Anak yang sedang dilakukan hospitalisasi dan peran keluarga sangatlah penting [17] 


\section{METODE PENELITIAN}

Desain penelitian dalam penelitian ini adalah quasi-eskperimen dengan rancanagan prapasca test dalam satu kelompok (one group pre and post test) untuk mengungkapkan hubungan sebab akibat (Notoatmodjo, 2010). Desain penelitian ini dilakukan dengan mengukur stress Hospitalisasi sebelum dilakukan bimbinganimajinasi dan setelah di lakukan bimbingan imajinasi akan di lakukaan kembali pengukuran Stress Hospitalisasi setelah dilakukan bimbingan imajinasi

Analisa pada penelitian ini adalah analisa univariat dan analisa bivariat.Analisis univariat yang dilakukan terhadap tiap variabel dari hasil penelitian, tujuan dari analisis ini hanya untuk menghasilkan distribusi dan persentase dari setiap variabel.Analisa bivariat yang dilakukan terhadap dua variable yang diduga berhubungan atau berkolerasi [18]Uji statistik yang digunakan untuk melihat dan membuktikan Pengaruh bmbingan imajinasi terhadap penurunan stress hospitalisasi pada anak usia prasekolah 7-12 tahun. Dengan melakukan pengujian melalui uji Mc Nemar yang menunjukkan ada Pengaruh Bimbingan Imajinasi terhadap Penurunan Stress Hospitalisasi dengan tingkat signifikan $p=0,000$

\section{HASIL DAN PEMBAHASAN}

\subsection{Hasil Penelitian}

\section{Tabel 1}

Gambaran Distribusi Stress Hospitalisasi Berdasarakan Umur

\begin{tabular}{cccc}
\hline No & Umur & Jumlah & Presentase \\
\hline 1 & 7 tahun & 10 & 45,5 \\
2 & 8 tahun & 6 & 27,3 \\
3 & 9 tahun & 5 & 22,7 \\
4 & 10 tahun & 1 & 4,5 \\
\hline & Jumlah & $\mathbf{2 2}$ & $\mathbf{1 0 0}$ \\
\hline
\end{tabular}

Dari Tabel 1 diatas dapat diketahui bahwa berdasarkan klasifikasi umur, terdapat 10 anak berumur 7 tahun (45,5\%), 6 anak berumur 8 Tahun (27,3\%), 5 anak berumur 9 Tahun $(22,7 \%)$, dan 1 anak berumur 10 tahun $(4,5 \%)$ 
Tabel 2

Gambaran Distribusi Stress Hospitalisasi Berdasarakan Jenis Kelamin

\begin{tabular}{cccc}
\hline No & Jenis Kelamin & Jumlah & Presentase \\
\hline 1 & Laki-laki & 10 & 45,5 \\
2 & Perempuan & 12 & 54,5 \\
\hline & Jumlah & $\mathbf{2 2}$ & $\mathbf{1 0 0}$
\end{tabular}

Dari Tabel 2 diatas dapat diketahui bahwa berdasarkan jenis kelamin, terdapat 10 anak laki-laki (45,5\%), dan 12 anak perempuan (54,5\%).

1. Variabel Univariat

Tabel 3

Gambaran Distribusi Stress Hospitalisasi Sebelum Bimbingan Imajinasi

\begin{tabular}{cccc}
\hline No & $\begin{array}{c}\text { Pretest Bimbingan } \\
\text { Imajinasi }\end{array}$ & F & \% \\
\hline 1 & Tidak Stress & 2 & 9.1 \\
2 & Stress & 20 & 90.9 \\
\hline & Jumlah & $\mathbf{2 2}$ & $\mathbf{1 0 0 \%}$ \\
\hline
\end{tabular}

Pada Tabel 3 dapat dilihat pre test bimbingan imajinasi terhadap penurunan stress hospitalisasi pada anak usia sekolah 7-12 tahun di ruang perawatan asoka RSUD Polewali Mandar yaitu responden yang mengalami tidak stress sebanyak 2 orang $(9,1 \%)$ dan yang mengalami stress sebanyak 20 orang $(90,9 \%)$.

\section{Tabel 4}

Gambaran Distribusi Stress Hospitalisasi Sesudah Bimbingan Imajinasi

\begin{tabular}{cccc}
\hline No & Post test Bimbingan Imajnasi & F & \% \\
\hline 1 & Tidak Stress & 9 & 40.9 \\
2 & Stress & 13 & 59.1 \\
\hline & Jumlah & $\mathbf{2 2}$ & $\mathbf{1 0 0 \%}$ \\
\hline
\end{tabular}

Dari Tabel 4 diatas dapat diketahui bahwa post test bimbingan imajinasi terhadap penurunan stress hospitalisasi pada anak usia sekolah 7-12 tahun di ruang perawatan asoka RSUD Polewali Mandar yaitu responden yang tidak mengalami stress 9 orang (40,9\%) dan mengalami stress 13 orang $(59,1 \%)$. 
2. Variabel Bivariat

Tabel 5

Pengaruh Bimbingan Imajinasi Terhadap Penurunann stress Hospitalisasi Pada Anak Usia Sekolah Di Ruang Perawatan Asoka RSUD Polewali Mandar

\begin{tabular}{|c|c|c|c|c|c|}
\hline & & \multicolumn{2}{|c|}{$\begin{array}{c}\text { Post test bimbingan } \\
\text { imajinasi }\end{array}$} & \multirow[t]{2}{*}{ Total } & \multirow[t]{2}{*}{$P$} \\
\hline Pretest & Tidak & Tidak Stress & Stress & & \\
\hline Bimbingan & Stress & 2 & $\mathbf{0}$ & 2 & \multirow{6}{*}{$=0.016$} \\
\hline \multirow[t]{3}{*}{ Imajinasi } & & $9.1 \%$ & $0 \%$ & $9.1 \%$ & \\
\hline & Stress & 7 & 13 & 20 & \\
\hline & & $31.8 \%$ & $59.1 \%$ & $90.9 \%$ & \\
\hline Total & & 9 & 13 & 22 & \\
\hline$\%$ & & $40.9 \%$ & $59.1 \%$ & $100 \%$ & \\
\hline
\end{tabular}

Berdasarkan Hasil tabulasi silang tabel 5 maka di dapatkan yang megalami stress hospitalisasi sebelum dilakukan bimbingan imajinasisebanyak 20 orang (90,9\%), dan yang tidak mengalami stress hospitalisasi sebanyak 2 orang $(9,1 \%)$ sedangkan yang mengalami stress hospitalisasi setelah bimbingan imajinasi sebanyak 13 orang $(59,1 \%)$, dan yang tidak mengalami stress hospitalisasi sebanyak 9 orang $(40,9 \%)$.

Dari hasil tabulasi silang di atas dapat dilihat bahwa bimbingan imajinasi berpengaruh untuk mengurangi stress hospitalisasi pada anak usia sekolah di ruang perawatan asoka RSUD Polewali Mandar.

\section{PEMBAHASAN}

Berdasarkan hasil tabulasi silang pada tabel 4.5 di atas maka didapatkan hasil bahwa yang megalami stress hospitalisasi sebelum dilakukan bimbingan imajinasi sebanyak 20 orang $(90,9 \%)$, dan yang tidak mengalami stress hospitalisasi sebanyak 2 orang $(9,1 \%)$ sedangkan yang mengalami stress hospitalisasi setelah bimbingan imajinasi sebanyak 13 orang $(59,1 \%)$, dan yang tidak mengalami stress hospitalisasi sebanyak 9 orang (40,9\%). Berdasarkan data di atas didapatkan hasil analisis data dengan menggunakan uji Mc Nemar Testdiperoleh nilai probabilitas (sig.) 0,016 dimana nilai p lebih kecil $(<)$ dari alpha 0,005, maka H0 ditolak, sehingga dapat dikatakan Bimbingan imajinasi berpengaruh terhadap penurunan stress hospitalisasi pada anak usia sekolah 712 tahun. Anak yang yang telah dirawat lebih dari satu kali tentu akan mempunyai pengalaman mengenai hospitalisasi dari pengalaman sewaktu dilakukan perawatan sebelumnya, dan telah mempunyai pengalaman tentang tindakan medis yang didapatkan selama perawatan. Sehingga akan mengurangi rasa cemas dan takut, tentu akan berbeda 
dengan anak yang pertama kali di rawat di rumah sakit, sejalan dengan penelitian oleh [19] menyatakan bahwa hospitalisasi anak dipengaruhi oleh pengalaman saat dilakukan perawatan sebelumnya. Hal ini terlihat dari hasil skor penurunan stress hospitalisasi sebesar 11,5\%. Peneliti mengungkapkan tidak ada pengaruh yang signifikan terhadap bimbingan imajinasi, beberapa factor yang dapat menyebabkan seperti : tempat, kondisi, waktu, (tempat khusus, tidak bising dan tidak banyak orang), namun kenyataannya pelaksanaanya tidak sesuai dengan semestinya, sehingga menyebabkan kurangnya konsentrasi pada anak saat dilakukan bimbingan imajinasi karena dipengaruhi oleh banyak stimulus yang diterima responden (anak). hal ini sejalan dengan pendapat oleh [20]bahwa kepribadian, perasaan rileks, tempat, (ruang khusus) umur, dan hasil akhir akan mempengaruhi keefektifan dari bimbingan.

Stress yang dialami anak karena kondisi sakit dan hospitalisasi juga sejalan dengan pendapat [8]bahwa stress yang dialami oleh anak dan keluarga dapat disebabkan oleh perubahan lingkungan yang berbeda dengan lingkungan rumah, kehilangan Kendali atas tubuhnya, ancaman dari penyakit serta adanya persepsi yang tidak meyenangkantentang rumah sakit disebabkan oleh pegalaman dirawat sebelumnya maupun pengalaman orang lain. Pendapat ini dibuktikan oleh penelitian yang membuktikan bahwa hospitalisasi anak dapat menjadi suatu pengalaman yang dapat menimbulkan trauma baik pada anak maupun orang tua sehingga menimbulkan reaksi tertentu yang sangat berdampak pada kerjasama anak dan orang tua dalam perawatan anak selama di rumah sakit [21] penelitian lain mengatakan bahwa metode guided imagery dan storytelling berpengaruh terdahap penurunan tingkat kecemasan anak pada usia prasekolah pada tindakan invasif, karena ditemani orang tua[22]

Berdasarkan observasi Hampir semua responden dapat melaksanakan intrevensi secara baik dan benar, Rata-rata menyukai gambar dan senang memimirkan gambar yang mereka pilih [23] Mengungkapkan bahwa seseorang dapat menvisualisasikan pengalaman terhadap hal-hal yang dialami dengan membayangkan seolah-olah hal itu benar-benar terjadi, Penelitian lain mengatakan untuk menurunkan hospitalisasi pada anak dapat dilakukan melalui audio [24] Pendapat [23] menyatakan bahwa cara yang efektif untuk merubah perilaku individu dapat dilakukan melalui bimbingan imajinasi. Teori lain yang menyatakan bahwa anak-anak sangat menyukai imajinasi dan senang memikirkan hal-hal yang menyenangkan, pernyataan ini di dukung oleh penelitian yang dilakukan oleh Huth, Daraiseh dkk (2012) menyatakan sebagian besar anak menyukai 
segala hal terdapat dalam panduan bimbingan imajinasi melalui $\mathrm{CD}$ dan suka membayangkan hal-hal yang membuatnya merasa senang, terdapat 3 anak tidak menyukai CD dan tidak membayangkan hal-hal yang menyenangkan, 6 anak tidak menyukai CD melalui komentarnya dari total yang dilakukan bimbingna yaitu 17 anak usia 7-12 tahun, bahwa 8 anak (50\%).

Untuk meningkatkan rasa percaya diri anak, anak tidak merasa sunyi, kreatif, mudah dalam berkomunikasi sehingga anak-anak akan berfikir hal-hal yang positif dapat dilakukan melalui Bimbingan imajinasi. Sejalan dengan pendapat [23] yaitu bimbingan imajinasi sangat membantu dalam meningkatkan kemampuan terutama pada psikomotirik serta dapat mengatasi rasa cemas saat berada dalam fase normal seperti dalam proses belajar, ujian, ataupun berbicara kepada orang atau di depan public. Metode Puzzle juga sangat efektif dalam mengatasi stress hospitalisai pada anak karena metode ini dapat mengalihkan fokus anak

Bimbingan imajinasi akan membuat kedekatan anak dengan tenaga keperawatan, meningkatkan rasa pecaya diri anak dalam membina hubungan terapeutik, sehingga anak tidak merasa sendiri, anak menjadi kreatif dalam berimajinasi hal-hal yang positif untuk mengurangi ketidaknyamanan anak selama dirawat. Hal ini sesuai pendapat ${ }^{[23]}$ yaitu bimbingan imajinasi juga memberikan kontribusi terhdap pencapaian keterampilan dan mengatasi kecemasan dalam situasi kehidupan normal yang mencakup belajar atau meningkatkan ketrampilan motorik, saat akan mengikuti ujian, atau berbicara di depan orang banyak/masyarakat. metode lain yang dapat digunakan untuk mengurangi stress hositalisasi dengan memberikan permainan Puzzle karena hal ini akan mengalihkan fokus anak akibat hospitalisasi ${ }^{[25]}$

\section{KESIMPULAN}

Berdasarkan hasil penelitian dan pembahasan yang telah dilakukan terhadap 22 responden tentang Pengaruh Bimbingan Imajinasi Terhadap Penurunan Stress Hospitalisasi Pada Anak Usia Sekolah 7-12 Tahun Di Ruang Perawatan Asoka RSUD Polewali Mandar, maka dapat disimpulkan bahwa Penurunan stress hospitalisasi pada anak usia 7-12 tahun sebelum di lakukan bimbingan imajinasi di Ruang Perawatan Asoka RSUD Polewali Mandar yaitu yang mengalami tidak stress sebanyak 2 orang $(9,1 \%)$ dan yang mengalami stress 20 orang $(90,9 \%)$. Setelah di lakukan bimbingan imajinasi di Ruang Perawatan Asoka RSUD Polewali Mandar yaitu yang mengalami tidak stress 9 rang (40,9\%) dan yang 
mengalami stress 13 orang $(59,1 \%)$. Oleh Karena itu Pengaruh Bimbingan Imajinasi Terhadap Penurunan Stress Hospitalisasi Pada Anak Usia Sekolah 7-12 Tahun Di Ruang Perawatan Asoka RSUD Polewali Mandar yaitu didapatkan hasil analisis data dengan menggunakan uji Mc. Nemar diperoleh nilai probabilitas (sig.) 0,016 lebih kecil $(<)$ dari alpha 0,05, maka H0 ditolak, sehingga dapat dikatakan bahwa bimbingan imajinasi berpengaruh terhadap penurunan stress pada anak usia 7-12 tahun di ruang perawatan asoka RSUD Polewali Mandar.

Oleh Karena itu Pengaruh Bimbingan Imajinasi Terhadap Penurunan Stress Hospitalisasi Pada Anak Usia Sekolah 7-12 Tahun Di Ruang Perawatan Asoka RSUD Polewali Mandar yaitu didapatkan hasil analisis data dengan menggunakan uji Mc. Nemar diperoleh nilai probabilitas (sig.) 0,016 lebih kecil $(<$ ) dari alpha 0,05, maka H0 ditolak, sehingga dapat dikatakan bahwa bimbingan imajinasi berpengaruh terhadap penurunan stress pada anak usia 7-12 tahun di ruang perawatan asoka RSUD Polewali Mandar.

\section{UCAPAN TERIMA KASIH}

Terimakasih Kepada Direktur sumber daya direktorat jenderal Pendidikan Tinggi Kementerian Pendidikan, Kebudayaan, Riset dan Teknologi sebagai pemberi dana dalam penelitian ini dan Terimakasih kepada Direktur RSUD polewali beserta jajarannya khususnya yang berada di ruang perawatan anak yang telah mendukung dan membantu dalam memberikan data maupun informasi dalam penelitian ini.

\section{DAFTAR RUJUKAN}

[1] A. yudianto dkk Lia kartika, Murti ani, Rina Mariana, Keperawatan anak dasar. Jakarta: yayasan kita menulis, IKAPI, 2021.

[2] F. intan Saputro heri, Anak sakit wajib bermain di rumah sakit. Ponorogo: FORIKES, 2017.

[3] R. diana Anggraini Sapariah, keperawatan anak. Pontianak, Kalimantan barat: Yudha English Gallery, 2018.

[4] Nursalam, Konsep \& Metode keperawatan edisi 2. Jakarta: Salemba medika, 2008.

[5] E. P. Sari and K. D. Rimandini, Asuhan Kebidanan Masa Nifas (Posnatal Care). Trans Info Media, 2014.

[6] tri cahyani nurlaila, wuri utami, keperawatan anak. Yogyakarta: leutika Nouvalitera, 2018. 
[7] pramesti pradira triwahyu Purna, prihatini monika Sawitri, and A. Yuliati, "The influence of THERAPY PLAY ON THE LEVEL OF COOPERATIVE CHILDREN," Pengaruh Ter. Bermain Terhadap Tingkat Koop. Anak Usia Prasekolah, vol. 4, no. 1, pp. 65-72, 2016.

[8] hidayat, pengantar ilmu keperawatan anak. 2015.

[9] D. I. Rumah, S. Di, and K. Palu, "Metode Bimbingan Imajinasi Rekaman Audio Untuk," Keperawatan Anak, vol. 1, no. 2, pp. 73-84, 2013.

[10] N. Ayuningtyas, A. Aprina, and A. Anita, "Pengaruh Biblioterapi 'Teruslah Semangat Nadi' terhadap Stres Hospitalisasi Anak Pra Operasi," J. Kesehat., vol. 11, no. 2, p. 251, 2020, doi: 10.26630/jk.v11i2.2030.

[11] Maria yashinta seran, "pengaruh bermain terapi slime terhadap respon biologis, psikologi dan perilku makan pada anak precshool yang menjalani hospitalisasi di ruang dahlia RSUD MGR GABRIEL, MANEK, SVD ATAMBUA,” 2017.

[12] rahaju ningtyas adi mulyono, puji idnryani, "literatur review pengaruh terapi distraksi audiovisual pada saat prosedur injeksi pada anak usia prasekolah saat hopitalisasi,” 2020.

[13] Y. Utami, "Dampak Hospitalisasi Terhadap Perkembangan Anak," J. Ilm. WIDYA, vol. 2, no. 2, pp. 9-20, 2014, [Online]. Available: http://digilib.mercubuana.ac.id/manager/t!@file_artikel_abstrak/Isi_Artikel_891255 124583.pdf.

[14] wiwin nursiam Warianti hadi, Yeni mila,Zainal Munir, "efektifitas penerapan metode family centered care terhadap anak pasien anak dengan stress hospitalisasi," 2019.

[15] oktaviani ni putu wiwik dkk paula veronica , Trisnadewi, ni wayan, keperawatan jiwa lanjutan. JAKARTA: IKAPI, 2021.

[16] M. Eni, "pengaruh orientasi terhadap tingkat kecemasan anak prasekolah di bangsal anak rumah sakit Bhakti Wira Tamtama Semarang," 2014.

[17] E. teresia dkk Pratiwi eka adhitia , fembi pembronia nona, konsep keperawatan anak. Bandung, Jawa Barat: Media Sains Indonesia, 2021.

[18] Notoatmodjo, keperawatan kesehatan komunitas. Jakarta: Salemba medika.

[19] Subardiah, "pengaruh permainan teripuitik terhadap kecemasan, kehilangan kontrol, dan ketakutan anak prasekolah selama dirawat dirumah sakit," 2009.

[20] B. Freiedman, M.M, Bowden, V.R, keperawatan keluarga riset teori dan praktik. 
2010.

[21] E. Hallstroom I, parents experience of different strategies for secure. pediactric nursing. 2012.

[22] J. R. Legi, S. Sulaeman, and N. H. Purwanti, "Pengaruh Storytelling dan GuidedImagery terhadap Tingkat Perubahan Kecemasan Anak Usia Prasekolah yang Dilakukan Tindakan Invasif,” J. Telenursing, vol. 1, no. 1, pp. 145-156, 2019, doi: 10.31539/joting.v1i1.496.

[23] jrank, guide imagery therapy. 2011.

[24] F. Masulili, "Metode Bimbingan Imajinasi Rekaman Audio Untuk Menurunkan Stres Hospitalisasi Pada Anak USia Sekolah Di Rumah Sakit Di Kota Palu,” J. Keperawatan Anak, vol. 1, no. 2, pp. 73-84, 2013, doi: 10.7454/msk.v17i2.xxxx.

[25] A. Priantiwi, P. Indrayani, and R. Ningtyas, "Literature Review : Pengaruh Puzzle Terhadap Kecemasan Anak Usia Prasekolah Akibat,” J. Nurs. Hleath, pp. 48-58, 2019. 